УДК 65.018:656.13

\title{
АКТУАЛЬНІ ПРОБЛЕМИ РОЗВИТКУ СИСТЕМИ МЕНЕДЖМЕНТУ ЯКОСТІ ПРОМИСЛОВОГО ПІДПРИЕМСТВА ЗАЛІЗНИЧНОГО ТРАНСПОРТУ
}

\author{
Іванілов О.С., д.е.н., професор, \\ Гришко О.А., аспірант (ХНУБА)
}

\begin{abstract}
У статті розкрито сутність поняття «розвиток системи менеджменту якості». Визначено та систематизовано основні причини, щз перешкоджають розвитку системи менеджменту якості промислового підприсмства залізничного транспорту. Запропонована тривимірна модель управління якістю діяльності зазначених підприємств, щуо передбачає переосмислення концепції управління якістю з відповідними корективами стратегічних пріоритетів; реінжиніринг ї̈ механізму функціонування й структурну перебудову; підтримку інновацій.
\end{abstract} якості.

Ключові слова: залізничний транспорт, промислове підприємство, система менеджменту

\section{АКТУАЛЬНЫЕ ПРОБЛЕМЫ РАЗВИТИЯ СИСТЕМЫ МЕНЕДЖМЕНТА КАЧЕСТВА ПРОМЫШЛЕННОГО ПРЕДПРИЯТИЯ ЖЕЛЕЗНОДОРОЖНОГО ТРАНСПОРТА}

\author{
Иванилов А. С., д. э. н., профессор, \\ Гришко О.А., аспирант (ХНУСА)
}

Харьковский национальный университет строительства и архитектуры

В статье раскрыта сущцость понятия "развитие системы менеджмента качества». Определены и систематизированы основные причины, препятствуюшие развитию системы менеджмента качества промышленного предприятия железнодорожного транспорта. Предложена трёхмерная модель управления качеством деятельности указанных предприятий, предполагающая переосмысление концепции управления качеством с соответствующиии коррективали стратегических приоритетов; реинжиниринг её механизма функционирования и структурную перестройку; поддержку инноваций.

Ключевые слова: жселезнодорожный транспорт, промыиленное предприятие, система менеджмента качества.

\section{ACTUAL PROBLEMS OF DEVELOPMENT OF SYSTEM OF QUALITY MANAGEMENT AT THE INDUSTRIAL ENTERPRISE OF RAILWAY TRANSPORT}

\author{
Ivanilov A. S., Doctor of Economics, Professor, \\ Hryshko O.A., postgraduate student \\ (Kharkiv National University of Construction and Architecture)
}

In article the essence of the concept "development of quality management system" is opened. The current state and conditions of development of the systems of quality management (SQM) at the domestic industrial enterprises of railway transport are analysed. Tendencies of development of innovations in the field of quality management abroad are considered. The subjective, economic and organizational and administrative reasons interfering development and improvement of SMK at the industrial enterprises of railway transport are defined. The three-dimensional model of quality management of activity of the specified enterprises assuming use of the following coordinated actions is offered: reconsideration of the concept of quality management with the corresponding amendments of strategic priorities, reengineering of its mechanism of functioning and restructuring, innovation.

Keywords: railway transport, industrial enterprise, the quality management system.

Постановка проблеми. До сфери комплексу, без яких неможливо підтримувати на залізничної галузі України входять підприємства i належному рівні стан інфраструктури та рухомого організації єдиного виробничо-технологічного складу, здійснювати перевезення вантажів i

(С Іванілов О.С.,

Гришко О.A.
Вісник економіки транспорту і промисловості № 49, 2015 
пасажирів. Серед них важливе місце належить промисловим підприємствам, які здійснюють різні види ремонту рухомого складу, навантажувальнорозвантажувальних машин, колісних пар; виготовлення вагонів, запасних частин для залізничного транспорту, устаткування для заводів і депо, залізобетонних шпал для залізниць тощо.

Однак на сьогоднішній час можна констатувати факт погіршення стану промислових підприємств залізничного транспорту (ППЗТ), що є наслідком зменшення інвестицій в їх діяльність, застарілості основних засобів, невідповідності продукції стандартам якості та інших факторів. Це зумовлює необхідність пошуку інструментів, які можуть сприяти переведенню ППЗТ у кращий стан. Одним із інструментів щодо досягнення вищезгаданої мети залишається сертифікація систем менеджменту якості ППЗТ на відповідність міжнародним стандартам серії ISO, забезпечення іх удосконалення і розвитку.

Аналіз останніх досліджень і публікацій. Дослідження теоретико-методологічних та прикладних аспектів проблеми управління розвитком підприємств проведено й висвітлено в роботах В.О. Василенко [4], О.С. Виханського [6], А.І. Наумова [6], Ф.Райхельда [12], Т.Тил [12] та ін. Проблемам розвитку теоретичних засад управління якістю на макро- і мікроекономічному рівнях присвячено роботи таких вітчизняних й зарубіжних учених і фахівців, як О.П. Богаченко [1], О.Ю. Бугрім [3], С.3.Весперіс [5], О.С.Іванілов [10], П.А.Орлов [11], М.Н. Смагіна [13], Б.І.Герасимов [13], Л.В.Пархоменко [13] та ін.

Однак, незважаючи на наявність значного наукового доробку, в сучасних умовах інтеграційних процесів та трансформації економіки, актуальним є питання аналізу проблем, що виникають при впровадженні, функціонуванні й розвитку системи менеджменту якості ППЗТ, що i зумовило необхідність проведення даного наукового дослідження.

Постановка завдання. Мета статті визначити сутність системи менеджменту якості (СМЯ); проаналізувати основні проблеми впровадження, функціонування й розвитку СМЯ на промислових підприємствах залізничного транспорту.

\section{Виклад основного матеріалу}

дослідження. Під системою менеджменту якості розуміють сукупність організаційної структури, методик, процесів і ресурсів, необхідних для здійснення загального керівництва якістю в організації [13, с.17]. Хоча управлінню якістю продукції в усіх країнах приділяється достатньо уваги, останніми роками сформувався новий підхід, нова стратегія в управлінні якістю. Вона характеризується такими ознаками [10, с. 575]: забезпечення якості розуміється не як технічна функція, яка реалізується якимось одним підрозділом, а як систематичний процес, що пронизує всю організаційну структуру фірми; новому поняттю якості повинна дорівнювати відповідна організаційна структура підприємства; питання якості актуальні не тільки в межах виробничого циклу, а й у процесі розробок, конструювання, маркетингу та обслуговування після продажу; якість повинна бути орієнтована на задоволення потреб споживача, а не виробника; всеохоплююче підвищення якості досягається тільки зацікавленою участю всіх співробітників.

Проведені нами дослідження [1-14] дозволяють стверджувати, що розвиток СМЯ ППЗТ- це:

- запланований довгостроковий процес, спрямований на визначення цілей, організацію і регулювання діяльності 3 управління яікстю, мотивацію і контроль;

- процес, що грунтується на системному підході та пов'язує потенціал організації 3 iii технологією, структурою та менеджментом;

- процес, в ході якого здійснюють організаційне проектування;

- процес навчання, який передбачає перепідготовку персоналу i $€$ одним із засобів формування організаційної культури.

Отже, поняття «розвиток систем менеджменту якості» ППЗТ можна трактувати як довготермінову діяльність щодо удосконалення процесів поліпшення якості (продукції, праці та ін.). Такий розвиток $є$ стратегічним напрямом, 3 одного боку, зростання загальної ефективності ППЗТ, а 3 іншого - підвищення почуття задоволеності споживачів (в першу чергу, Укрзалізниці) та поліпшення умов праці співробітників. Це процес позитивних і якісних змін на ППЗТ, які зачіпають головним чином організаційну структуру підприємства, засоби діяльності та взаємодії.

За останні роки спостерігається динаміка зростання числа вітчизняних ППЗТ, які з метою досягнення конкурентних переваг на ринку, впроваджують СМЯ з подальшою їх сертифікацією на відповідність вимогам стандартів ISO. Однак, не завжди цю роботу вдається виконати успішно. Серед проблем, пов'язаних 3 упровадженням i функціонуванням СМЯ на ППЗТ, можна виділити наступні основні проблеми за категоріями, які відображені на рисунку 1.

До першої категорії можна віднести проблеми суб'єктивного характеру, до яких можна віднести, в першу чергу, проблеми пов'язані 3 персоналом ППЗТ. Так, не поодинокі випадки, коли співробітники названих підприємств сприймають поліпшення якості, наприклад, ведення обліку витрат на якість, як додаткове навантаження і не бачать в цьому необхідності. 
Нововведення з боку працівників відділу (служби, 3 недовірою і нерозумінням. департаменту) якості сприймаються працівниками

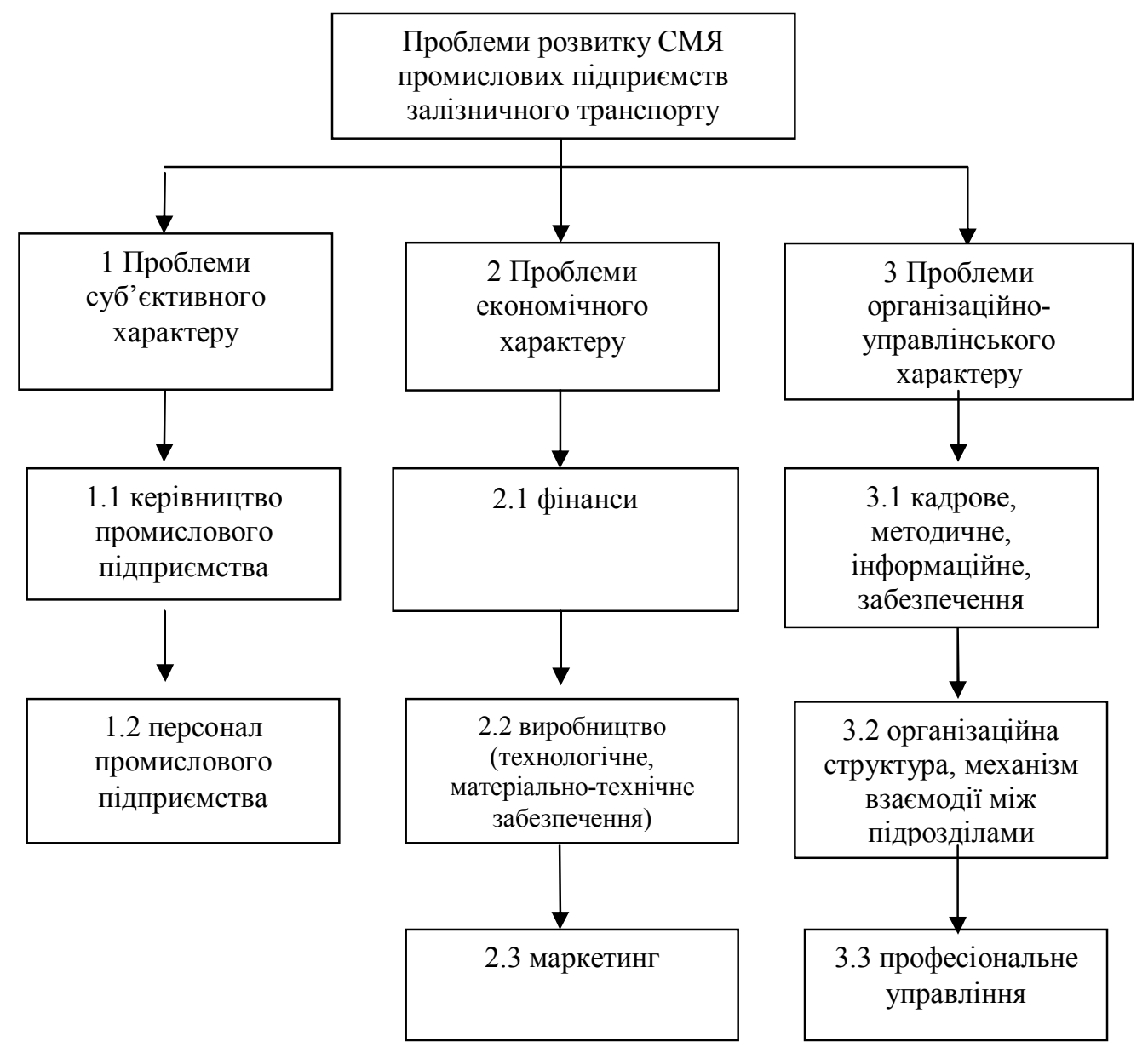

Рис. 1. Проблеми розвитку систем менеджменту якості промислових підприємств залізничного транспорту

До проблем суб’єктивного характеру також керівництвом підприємства. Наприклад, це не завжди правильні цільові настанови керівництва підприємства i ментальне сприйняття поняття якості 3 їхнього боку (переважна кількість керівників підприємств тлумачать якість як ступінь виконання технічних умов та вимог замовника, що пред'являються до продукції підприємства). Сьогодні керівники ППЗТ здійснюють управління фінансами і кадрами, поряд з цим, відповідно до міжнародних стандартів на підприємствах повинно бути забезпечено управління процесами i проектами. Тому в такій ситуації необхідне переосмислення поняття якості з боку керівників підприємств, в іншому випадку - підприємством буде вироблятися продукція, яка не буде користуватися попитом з боку споживачів.

На жаль, мають місце випадки, коли керівник підприємства своєю головною метою вважає не створення дійсно ефективної СМЯ, а отримання сертифіката, не враховуючи, що орган, можна віднести і проблеми, пов'язані з вищим який видає цей документ, має право достроково скасувати його, коли виявляться суттєві недоліки у функціонуванні системи [11].

До другої категорії можна віднести проблеми економічного характеру. Серед проблем цієї групи насамперед слід виділити такі: недостатній рівень платоспроможності ППЗТ; застарілість основних засобів; недостатність обігових коштів, недосконалість механізму середньо- та довгострокового кредитування виробників і споживачів продукції та високі ставки кредитування; відсутність реальних джерел фінансування, що призводить до унеможливлення реконструкції та технічного переоснащення промислових підприємств i забезпечення за рахунок цього високої якості продукції для залізничного транспорту; відсутність фінансових механізмів та інструментів, що створюють зацікавленість в інноваціях, а також стимулюють науково-дослідні і дослідно-конструкторські 
роботи, низький рівень інноваційної активності; обмежений внутрішній попит на продукцію (в першу чергу - 3 боку головного споживача Укрзалізниці).

Іншою групою проблем економічного характеру $є$ проблеми виробництва. Основні проблеми, що свідчать про наявність на досліджуваних підприємствах таких проблем: низька якість продукції, що випускається; високий рівень браку; неповне використання виробничих потужностей; неорганізована діяльність по роботі 3 постачальниками; низька якість матеріалів, що поставляються; обмеженість ресурсів; несертифіковані системи якості.

Ще однією групою економічних проблем $\epsilon$ відсутність або недостатня ефективність діяльності систем маркетингу та збуту продукції. Основними проблемами цієї групи $\epsilon$ : незнання реальної ситуації на ринку; нерівні умови конкуренції; відсутність зворотного зв'язку зі споживачами; мала частка ринку збуту; низький платоспроможний попит; відсутність оперативності отримання інформації про ринки збуту; невідповідність вимог в контрактах; затримки в постачанні продукції.

Головною проблемою економічної групи $\epsilon$ проблеми, пов'язані з відсутністю налагоджених ефективних зворотних зв'язків зі споживачами, постачальниками, персоналом та іншими зацікавленими цільовими аудиторіями. Відділи матеріально-технічного постачання і збуту ППЗТ знаходяться поза системами управління. Відсутня співпраця 3 постачальниками по створенню у них ефективних систем якості для підвищення якості їх продукції і зниження іiї собівартості.

Відповідно до стандартів ISO ключовим фактором ефективності СМЯ та сталого розвитку підприємств є побудова взаємовідносин зі споживачами, тому основні зусилля підприємства повинні спрямовуватися не на короткостроковий результат конкретної угоди, а на встановлення відносин зі споживачами, прибутковими в довгостроковій перспективі. Як відомо, взаємовідносини зі споживачами тим цінніші, чим довше підприємство співпрацює 3 найбільш вигідними для нього споживачами. Результати досліджень доводять, що в більшості галузей прибуток від кожного споживача зростає в міру його співпраці з підприємством, а для компенсації втрат від одного потенційного клієнта необхідно залучити кілька нових [12].

Керівники ППЗТ усвідомлюють значення стійких взаємовідносин зі споживачами. Вони розуміють, що прибутковість споживачів залежить від терміну співпраці з підприємством і від тих методів та інструментів, які використовуються для зміцнення цих відносин. Але найчастіше можна спостерігати необгрунтований характер прийнятих рішень стосовно взаємодії виробників між собою і споживачами. Рішення грунтуються переважно на інтуїції і досвіді керівників ППЗТ. Багато питань в області формування взаємовідносин зі споживачами стратегічно не опрацьовані i не закріплені функціонально. В більшості випадків ППЗТ сегментують своїх споживачів за ступенем ïx важливості i виробляють диференційовану політику по відношенню до різних груп. У той же час диференціювання споживачів часто проводиться без серйозного аналізу й обгрунтування. У якості найважливіших факторів закріплення споживачів за підприємством виступають позитивні емоції; зниження ризику; особисті зв'язки споживачів 3 керівництвом та їх моральні зобов'язання по відношенню до підприємства. При цьому найбільш ефективні технічні, когнітивні, правові та просторові бар'єри - в рейтингу факторів закріплення споживачів за підприємством займають нижні позиції.

До третьої категорії можна віднести проблеми організаиійного характеру. Це, перш за все, відсутність достатньої кількості кваліфікованих спеціалістів у сфері якості (продукції, процесів, діяльності) для розроблення, впровадження та сертифікації систем управління якістю. В Україні недостатньо спеціалістів, які добре орієнтуються у системах управління якістю та їх впровадженні на ППЗТ, виробничі процеси яких $є$ специфічними. Вирішення цього питання повинно ініціюватися державними органами, зокрема, профільними міністерствами.

Виділеною серед інших проблем $\epsilon$ недостатня мотивація персоналу і вибір неефективної для конкретних робіт системи оплати праці. Найчастіше на виробничих підприємствах для винагороди робочого персоналу за виконану роботу використовується відрядна система оплати праці; працівник отримує заробітну плату за реально підраховані результати праці. В результаті персонал буде прагнути швидше виконати роботу, роблячи акцент не на іï якість, а на кількість. Таким чином, у більшості випадків збільшується число браку, а відповідно і витрати робочого часу, i сировини та матеріалів. Саме тому керівнику підприємства необхідно більш відповідально ставитися до вибору системи оплати праці $[8$, с. 9].

Має місце проблема відсутності необхідної теоретико-методологічної і методичної бази у сфері управління якістю, зокрема надійного методу кількісної оцінки економічної ефективності створення, сертифікації і функціонування СМЯ на ППЗТ. Тому вирішення цієї проблеми $\epsilon$ дуже необхідним кроком, який дасть змогу частково уникнути помилок, зроблених підприємствами в процесі запровадження і функціонування систем управління якістю. Потребують подальших методичних розробок щодо впровадження i 
розвитку СМЯ: опис процесу оцінки задоволеності споживачів; критеріїв і методів оцінки результативності процесів, критеріїв вимірювання цілей у сфері якості; аналізу ефективності СМЯ (внутрішні аудити систем менеджменту якості зводяться до перевірки впровадження документів системи, залишаючи без уваги перевірку результативності процесів); аналізу характеристик i тенденцій процесів i продукції, зокрема можливості запобіжних дій.

На жаль, на вітчизняних підприємствах відсутній точний облік внутрішніх затрат і втрат, зумовлених низькою якістю, через недосконалість нормативних документів. Так, Типове положення 3 планування, обліку й калькулювання собівартості продукції (робіт, послуг) у промисловості № 473 передбачає, що в собівартість непоправного браку включаються всі прямі витрати, частина витрат на утримання та експлуатацію устаткування, загальновиробничі витрати [11, с. 23].

Найбільш поширеною серед низки можливих організаційних проблем $є$ низький рівень організації інформаційної інфраструктури ППЗТ, відсутність інтегрованого інформаційного центру продовж всього ланцюга управління якістю. Збір та аналіз управлінської інформації в ході впровадження i поліпшення СМЯ, а також внутрішня статистична звітність оптимізовані не повністю, відсутня єдина система, що забезпечує вимір, збір i аналіз інформації про якість продукції і процесів, що не дозволяє своєчасно і максимально об'єктивно оцінювати діяльність ППЗТ і ефективно управляти ресурсами i процесами. Більшість підприємств раціоналізують свою інфраструктуру за рахунок регламентування операцій обробки даних, консолідації систем моніторингу або залучення референтних моделей організації бізнес-процесів. Реалізація цих методів, взятих окремо, не дає довгострокового ефекту. Тому, необхідно аналізувати стан зрілості інформаційної інфраструктури, іï взаємозв'язок 3 потребами та загальною стратегією промислових підприємств залізничного транспорту.

Серйозними, на думку авторів, $є$ такі організаційні проблеми, як ієрархічні організаційні структури i розвинені вертикальні внутрішні комунікації (замість горизонтальних зв'язків); відсутність чіткого розподілу меж повноважень та відповідальності при взаємодії підрозділів ППЗТ в ході реалізації ними своїх функцій щодо поліпшення якості. Роботи по інжинірингу системи управління якістю повинні випереджати реінжиніринг всієї організаційної структури ППЗТ, на певному етапі стати його частиною, тобто частиною всіх узгоджених між собою робіт 3 оновлення організаційної структури названих підприємств.
Головною проблемою професіонального управління СМЯ є проблема відсутності орієнтації ППЗТ на управління процесами (в кращому випадку дана норма задокументована, але не впроваджена в практику). Поряд 3 цим, однією 3 ключових концепцій, що містять стандарти ISO серії 9000, є необхідність впровадження процесного підходу до управління якістю [9]. Процесний підхід передбачає побудову процесів на підприємстві та управління якістю за допомогою цих процесів. Стандарти містять ряд рекомендацій i вимог до організації процесного підходу щодо управління якістю. На нашу думку, основними 3 цих вимог є [9]: «визначити системи та процеси, які були б зрозумілі та керовані в напрямку підвищення їхньої результативності й ефективності»; «забезпечити результативне й ефективне функціонування процесів і управління ними».

До числа основних проблем професіонального управління розвитком СМЯ також слід віднести: відсутність кількісних та якісних показників діяльності менеджерів; неконкретна постановка завдань і тривалий час для ï вирішення; недостатній інструктаж i координація; нечіткий розподіл обов'язків щодо забезпечення якості продукції, праці, процесів, діяльності підприємства в цілому; проблема виконання документів СМЯ; недостатність делегування відповідальності; недооцінювання ступеня серйозності перешкод; невміння менеджерів розробляти стратегічні альтернативи щодо розвитку СМЯ і забезпечувати фактичне виконання рішень; незнання методів аналізу ситуацій, управлінських технологій тощо; відсутність системи обліку витрат на поліпшення СМЯ; фрагментарність діяльності 3 управління якістю.

Резюмуючи сказане, важливо підкреслити, що переважна більшість перерахованих проблем діяльності ППЗТ з упровадження і поліпшення СМЯ є наслідком суб'єктивних і організаційноуправлінських причин: відсутність зацікавленості у запровадженні стандарту, негативне сприйняття стандарту як інструменту додаткового навантаження та ускладнення виконання посадових обов'язків; опір персоналу; нерозуміння необхідності змін; недостатній рівень управлінських знань 3 питань якості у керівництва та середньої ланки менеджменту; невміння менеджерів управляти змінами.

Що стосується західних i японських фахівців, вони вже давно усвідомили серйозність наслідків опору змінам i накопичили чималий досвід подолання цього опору. Наприклад, японці застосовують кілька принципів управління, мотивації та стимулювання, що дозволяють найбільш безболісно і швидко впровадити СМЯ і 
підтримувати ії функціонування та поліпшення. До таких принципів належать: гарантія зайнятості та створення обстановки довіри; постійна присутність керівництва на виробництві; гласність і цінності корпорації; управління, засноване на інформації управління, орієнтоване на якість [9].

Досвід японських компаній демонструє наступні відмінності від вітчизняної практики: управлінський персонал розташовується у виробничих приміщеннях; організовуються i успішно функціонують гуртки якості; майстри вирішують проблеми відразу, щоб уникнути безвідповідальності та апатії з боку співробітників, які виникають в результаті того, що після події проходить багато часу, а причина залишається непоміченою $[7 ; 10]$. Роблячи акцент на задоволеності персоналу, зарубіжні компанії досягають найменшого опору 3 боку співробітників при впровадженні і поліпшенні СМЯ.

Варто звернути увагу на тенденції розвитку інновацій в області менеджменту якості за кордоном. Активний цикл інновацій в області менеджменту якості на основі концепції сталого розвитку розпочала Франція. У червні 2003 р уряд Франції схвалив Національну стратегію сталого розвитку та на іiі основі французька організація по стандартизації (AFNOR) опублікувала Керівництво «Сталий розвиток. Соціальна відповідальність корпорацій. Керівництво з обліку вкладу «сталого розвитку». Нормативні розробки з питань сталого розвитку створено також у Великобританії, у вигляді рекомендацій SIGMA, в Iталії-Q-RES, у Німеччині - VMS [14].

Висновки дослідження i перспективи подальших розвідок у цьому напрямку. Отже, розвиток систем менеджменту якості на ППЗТ являє собою динамічний $\mathrm{i}$ неперервний процес адаптації організаційних змін до факторів зовнішнього середовища. 3 метою усунення виявлених проблем та забезпечення успішного розвитку СМЯ промислове підприємство залізничного транспорту, перш за все, повинно уникати іiі формальної розробки, а також здійснювати розвиток СМЯ на основі тривимірної моделі, що передбачає наступні скоординовані дії:

- по-перше, переосмислення концепції управління якістю 3 відповідними корективами стратегічних пріоритетів. Переосмислення концепції управління якістю передбачає перехід від іiі сприйняття як системи управління якістю продукції - до системи стратегічного управління якістю процесів 3 метою постійного поліпшення діяльності промислового підприємства залізничного транспорту;

- по-друге, реінжиніринг механізму функціонування СМЯ, спрямований на переосмислення способу здійснення діяльності на всіх ієрархічних рівнях, формування нової організаційної (зокрема, виробничої) культури та якісно нових підходів до маркетингу (зокрема, маркетингу взаємовідносин зі споживачами та постачальниками). Реінжиніринг механізму функціонування СМЯ має бути націлений на удосконалення процесів управління, що забезпечують основні функції підприємства; перебудову організаційних структур, що мають відповідати визначеним раціональним способам управління; перепроектування процесів;

- no-третє, підтримку інновацій і передачу знань. Система менеджменту якості має стати стимулом до нововведень, впровадження інноваційних технологій у виробництво, створення постійного інноваційного процесу - перетворення наукових знань в інновацію, в результаті чого на ринку з'являється нова продукція, цінність якої визнається споживачами і іншими зацікавленими сторонами.

В подальших наукових дослідженнях перспективним $є$ пошук оптимальних механізмів пристосування класичних СМЯ до особливостей функціонування ППЗТ на сучасному етапі їхнього розвитку.

\section{СПИСОК ЛІТЕРАТУРИ}

1 Богаченко О. П. Теорія i практика оцінювання ефективності використання системи менеджменту якості: монографія / О. П. Богаченко. - Запоріжжя : ЗНТУ, 2013. - 246 с.

2 Большой экономический словарь : 26500 терминов / А. Н Азрилиян, О. М.Азрилиян, Е. В.Калашникова и др; Ред. А. Н.Азрилиян. - 7-е изд., доп. - М. : Институт новой экономики, 2011. $1472 \mathrm{c}$.

3 Бугрім О. Ю. Витрати промислових підприємств на впровадження системи управління якістю продукції / О. Ю. Бугрім // Держава та регіони. Серія: Економіка і підприємництво. 2011. - №2. - С. 129-134.

4 Василенко В.А Менеджмент устойчивого развития предприятий: монографія / Василенко В.А. - К.: ЦУЛ, 2005. - 648 с.

5 Весперіс С.3. Формування основних засад реалізації комплексної програми управління якістю / С.З.Весперіс, С.О. Мельников // Потенціал економічного розвитку в контексті європейської інтеграції: збірник наукових праць 3 актуальних проблем економічних наук. Дніпропетровськ: ВД Гельветика - 2013. - С.30-37.

6 Виханский О.С. Менеджмент: Учеб. / О.С. Виханский, А.И. Наумов. - [3-е изд.]. - М.: Гардарики, 1999. - 528 с.

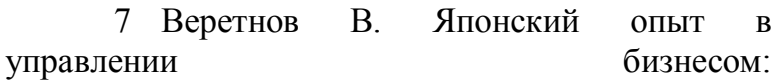
http://www.management.com.ua/hrm/hrm045.html.

8 Впровадження системи контролю якості 
на вітчизняних підприємствах як запорука економічного розвитку України / Білоконь Т.В., Позднякова О.К. // Вісник НТУ «ХПІ». Серія: Актуальні проблеми управління та фінансовогосподарської діяльності підприємства - Харків: НТУ «ХПІ». - 2012 . - No 58(964). - C. 8-12.

9 ДСТУ ISO 9001-2001. Системи управління якістю. Вимоги. - На заміну ДСТУ ISO 9001:95, ДСТУ ISO 9002:95, ДСТУ ISO 9003:95. К.: Держстандарт України, 2001. - 23 с.

10 Іванілов О. С. Економіка підприємства: підруч. [для студ. вищ. навч. закл.] / О. С. Іванілов — К.: Центр учбової літератури, 2009. — 728 с.

11 Орлов П. Економічні аспекти впровадження системи менеджменту якості на промислових підприємствах / П.А. Орлов //
Управління економікою: теорія та практика - 2008. - №2 - С.17-26.

12 Райхельд Ф., Тил Т. Эффект лояльности: движущие силы экономического роста, прибыли и непреходящей ценности / Ф. Райхельд, Т. Тил пер. с англ. М.: Вильямс, 2005. - 345 с.

13 Смагина М.Н. Процессы системы менеджмента качества: монография / М.Н. Смагина, Б.И.Герасимов, Л.В.Пархоменко под науч. ред. д-ра экон. наук, проф. Б.И. Герасимова Тамбов: Изд-во Тамб. гос. техн. ун-та, 2006. - 100 c.

14Швец В. Устойчивое развитие и менеджмент качества // Стандарты и качество. 2005. - № 11. - C.38-43.

Експерт редакційної колегії к.е.н., доцент УкрДУЗТ Полякова О.М.

\title{
УДК 656.2 \\ ФОРМУВАННЯ КОНЦЕПТУАЛЬНОГО ПІДХОДУ ДО УПРАВЛІННЯ ВИТРАТАМИ ПІДПРИЕМСТВ ЗАЛІЗНИЧНОГО ТРАНСПОРТУ
}

\author{
Карачарова К.А., к.е.н, доцент, \\ Павленко Т.С., махістр (УкрДУЗТ)
}

В статті обтрунтована необхідність побудови нового дієвого концептуального підходу до управління витратами підприсмств залізничного транспорту. Проведено критичний аналіз теоретичних напрацювань із зазначеної проблематики, а також виділено головні особливості існуючих концеепиій управління витратами. На базі проведеного дослідження окреслено особливості процесу управління витратами. Визначено концепції управління витратами, які слід прийняти в якості базових при формуванні нового дієвого концептуального підходу до управління витратами підприємств залізничного транспорту, окреслено ключові його положення, а також виділені стратегічні одиниці бізнесу, щзо відповідальні за їх виконання. транспорт.

Ключові слова: витрати, управління витратами, концепція, підприємство, залізничний

\section{ФОРМИРОВАНИЕ КОНЦЕПТУАЛЬНОГО ПОДХОДА К УПРАВЛЕНИЮ ЗАТРАТАМИ ПРЕДПРИЯТИЙ ЖЕЛЕЗНОДОРОЖНОГО ТРАНСПОРТА}

\author{
Карачарова К.А., к.э.н, доцент, \\ Павленко Т.С. магистр (УкрГУЖТ)
}

В статье обоснована необходимость построения нового действенного концептуального подхода к управлению затратами предприятий железнодорожного транспорта. Проведен критический анализ теоретических наработок по указанной проблематике, а также выделены главные особенности существующих конщепџий управления затратами. На базе проведенного исследования определень особенности прочесса управления затратами. Определены концепции управления затратами, которые следует принять в качестве базовых при формировании нового действенного концептуального подхода $\kappa$ управлению затратами предприятий железнодорожного транспорта, определены ключевые его положения, а также выделены стратегические единицы бизнеса, ответственные за их выполнение.

Ключевые слова: затраты, управление затратами, концепция, предприятие, железнодорожный транспорт.

(C) Карачарова К.A.,

Павленко Т.C.

Вісник економіки транспорту і промисловості № 49, 2015 